\title{
Stakeholder Theory(ies): Ethical Ideas and Managerial Action
}

\author{
R. Edward Freeman · Gianfranco Rusconi • \\ Silvana Signori $\cdot$ Alan Strudler
}

Published online: 5 July 2012

(C) Springer Science+Business Media B.V. 2012

Stakeholder theory, as its proponents make plain, is best regarded practically or pragmatically, rather than as theory in any rarified sense. In the realm of many practicing social scientists, a theory will be assessed in terms of the comprehensiveness of its account of the problems it addresses. Stakeholder theory has no such comprehensive or explanatory aims. Instead it aims to be useful, to provide tools that managers can use to better create value for the range of their constituents, tools that constituencies can use to improve their dealings with managers, and tools that theorists can use to better understand how value creation and trade take place. With a better understanding of how these tools work, we may hope to see how different moral perspectives suggest different interpretations of the value that managers create. Moreover, using the language of stakeholders makes it easier for business executives and theorists to see business and ethics as integrated, rather than always in conflict.

If stakeholder theory is best understood pragmatically, then we, as academics, face hard questions about how to assess, criticize, refine, or develop stakeholder theory.

R. Edward Freeman

Darden School, University of Virginia, Charlottesville, VA, USA

e-mail: FREEMANE@Darden.virginia.edu

G. Rusconi - S. Signori

University of Bergamo, Bergamo, Italy

e-mail: ruscgfr@unibg.it

S. Signori

e-mail: ssignori@unibg.it

A. Strudler $(\bowtie)$

The Wharton School, University of Pennsylvania, Philadelphia, USA

e-mail: strudler@wharton.upenn.edu
Social scientists typically assess theories in terms of their fecundity, and the truth or falsity of their implications. It is not obvious that counterpart critical categories exist for thinking about tools. So how should academics think about questioning, developing, or refining stakeholder theory? We believe that the articles collected in this issue provide distinctive answers to this question, thus suggesting different ways in which stakeholder theory may be conceived.

The first three articles challenge the boundaries of stakeholder management, offering distinctive conceptions of stakeholders. David Silver examines the way businesses should take into account the interests of the "citizen stakeholders" in the liberal democratic societies in which they operate. Seeking guidance from contractualist moral theory, Silver shows how a contractualist version of stakeholder theory plausibly identifies the relevant moral interests of both shareholders and "citizen stakeholders," and defends a method for giving their interests appropriate consideration. The issue of citizenship is undertaken, from a different perspective, in articles by Kevin Gibson and by Daniel Puffer et al. Gibson proposes a re-thinking of the environment as stakeholder. He recommends moving from broad notions of preserving nature to a more concrete idea of human sustainability. In his view "leaders should take on multiple roles: a steward of values and resources; a good citizen; a servant to others, a visionary who provides inspiration and perspective with respect to a desirable future; and a coach who can bring together people from multiple backgrounds to realize a common vision." Puffer et al. investigate the use of favors by managers to accomplish business goals, and show how focus on favors leads to recognizing society as a stakeholder. The authors employ institutional theory to explain why favors are relied upon, and Integrative Social Contracts Theory (Donaldson and Dunfee 1999) to explore when the use of favors may be 
considered ethical. As a consequence, they include in the notion of stakeholder, not only the giver and receiver of a favor, but also the larger society in which individuals act.

The next three articles underline how managers perceive the process of stakeholder management. Hans-Jörg Schlierer, Andrea Werner, Elisabeth Garriga, Yves Fassin, Silvana Signori, Heidi von Weltzien Hoivik, and Annick van Rossem together present the result of their crossnational study on how European SME owner-managers make sense of stakeholder management. The comparative analysis shows that the institutional, cultural, and linguistic context can influence owner-managers' sensemaking of stakeholder management, and suggests stakeholder theorists should devote more attention to the socio-cultural environments that shape economic activity in different parts of Europe. Using media texts reporting on the case of a foreign investment project, Johanna Kujala, Anna Heikkinen, and Hanna Lehtimäki examine stakeholder relationships in a conflict situation. Their study confirms that stakeholders are likely to co-operate with other actors who have similar interests, and proposes that these relationships evolve constantly as interests change in different contexts. Moreover, it shows how "the ethical premises of interest justification allow for building a common ground on mutual understanding and the co-operative nature of joint value creation. Such an effort is a display of a set of different values where both strategic and ethical dimensions in stakeholder relationships should be taken into account". Mario Minoja advances a theoretical framework that links together stakeholder management, stakeholder commitment to co-operate with the firm, key decision makers' ethical commitment, and firm strategy. Drawing on this framework, Minoja calls for the integration of strategy and ethics by proposing a three-level conceptual model that distinguishes the objectives, the field, and the levers of integration.

The last group of articles delves into the nature of relationships among stakeholders. Yves Fassin emphasizes the role of reciprocity and responsibility of stakeholders toward the firm and toward other stakeholders. Fassin underlines how various attributes differ for different categories of stakeholders and proposes a classification into stakeowners, stakewatchers, stakekeepers, stakeseekers. The theme of stakeholders' responsibility to or for "their" corporation is tackled also by Martin Sandbu, with specific reference to the moral responsibility of investors or "financiers" for corporate activity. Sandbu maintains that "a notion of complicity is the only tenable ground for holding investors liable to any meaningful extent and sketches an account of complicity based on the recent philosophical literature on collective intention and collective action". Reflecting on financial services firms on Wall Street, Lauren Purnell, and Ed Freeman investigate how financial firms may view ethics as a separate domain from the core business of the organizations. The results are a "blind spot" that "stifles meaningful exchanges with stakeholders attempting to address the need for reform". They therefore suggest, as a conclusion, that ethical considerations are "less about casting a value judgment and more about creating a process of meaningful conversation throughout an institution and its stakeholders".

This special issue of the Journal of Business Ethics presents a selection of papers from the 3rd BergamoWharton Joint Conference on Business Ethics entitled "Stakeholder Theory(ies): Ethical bases and managerial applications" held in Bergamo the 1st and 2nd July 2010. As guest editors of this special issue, we would like to thank all colleagues who agreed to serve as reviewers for this issue, as well as for the conference. We especially express our gratitude to all the participants to the conference who contributed in various ways to make this event unique.

\section{Introduction}

Citizens as contractualist stakeholders (David Silver)

Stakeholders and sustainability: an evolving theory (Kevin Gibson)

A stakeholder approach to the ethicality of BRIC-firm Managers' use of favors (Daniel J. McCarthy, Sheila M. Puffer, Denise Dunlap-Hinkler, Alfred M. Jaeger)

How do European SME owner-managers make sense of 'stakeholder management'?-Insights from a crossnational study (Hans-Jörg Schlierer, Andrea Werner, Elisabeth Garriga, Yves Fassin, Silvana Signori, Heidi von Weltzien Hoivik, Annick van Rossem)

Understanding the nature of stakeholder relationships: an empirical examination of a conflict situation (Johanna Kujala, Anna Heikkinen, Hanna Lehtimäki)

Stakeholder management theory, firm strategy, and ambidexterity (Mario Minoja)

Stakeholder management, reciprocity, and stakeholder responsibility (Yves Fassin)

Stakeholder duties: on the moral responsibility of corporate investors (Martin Sandbu)

Stakeholder theory, the fact/value dichotomy, \& the normative core: how Wall Street stops the ethics conversation (Lauren Purnell and R. Edward Freeman). 